\title{
Mathematical Literacy of Students Who Have High Mathematical Disposition in Solving PISA-Like Mathematics Problems
}

\author{
Winda Ardi Rahmawati ${ }^{1, *}$ Budi Usodo ${ }^{2}$ Laila Fitriana ${ }^{3}$ \\ ${ }^{1}$ Postgraduate School of Mathematics Education, Faculty of Teacher Training and Education, Universitas \\ Sebelas Maret, Indonesias \\ ${ }^{2,3}$ Faculty of Teacher Training and Education, Universitas Sebelas Maret, Indonesia \\ *Email: ardiwinda.11@student.uns.ac.id
}

\begin{abstract}
This research aims to describe the mathematical literacy skills of students who have a high mathematical disposition in solving problems similar to PISA. The research methods in this study use qualitative descriptions. The subject of the study was a student of class IX D junior high school IT Nur Hidayah Surakarta consisting of 29 students. Of the 29 students taken 2 students who had a high mathematical disposition which was then established as a research subject. The instruments used are mathematical disposition questionnaire instruments, literacy test instruments and interview guidelines. Data analysis using mathematical literacy indicators based on research results that have a high mathematical disposition is able to solve mathematical literacy problems up to level 5 with the right and correct procedures and strategies. The subject is able to mention the information in the problem and then connect it to the problems that occur in everyday life. The subject is also able to understand the concept so that the steps of the workmanship are based on mathematical reasoning. At level 6 the subject does not understand the meaning of the problem but at this level the subject already has a strong determination to complete so as to produce a final answer that is accompanied by reason although still not accurate. Subjects with a high mathematical disposition are able to communicate results as well as reasons very well and confidently.
\end{abstract}

Keywords: Mathematical literacy, Mathematical disposition, PISA.

\section{INTRODUCTION}

Mathematical literacy is a person's ability to read mathematics in various contexts of daily life. Based on the PISA framework, mathematical literacy skills are students' ability to formulate, apply, and interpret mathematics in a variety of contexts that include mathematical reasoning and also using concepts of procedures, and mathematical facts [1]. Mathematical literacy can help in understanding the role and usefulness of mathematics while using it to make informed decisions as a constructive, caring, and thinking citizen. Mathematics is so related to today's way of life that one cannot fully understand the information around it without a basic understanding of mathematical ideas [2].

One of the international assessment programs of knowledge and skills known as PISA (Programme for
International Student Assessment) has compiled a variety of technical assessments that can help the government in seeing and assessing the results of the education system that can be accepted both nationally and internationally. PISA has its own measure of knowing students' mathematical literacy skills. These capabilities must meet three dimensions, namely context, content and process dimensions. The three dimensions are described as follows: 1) the situation or context; 2) content; and 3) process. The three dimensions describe the place where events occur in general, the material studied and the stage of completion. To measure the level of mathematical literacy ability of students there is an indicator consisting of 6 levels, where at each level has its own characteristics that the higher the level achieved, the higher the student's mathematical literacy ability [3]. Indicators of mathematical literacy skills can be seen in the following table: 
Table 1. Indicators of mathematical literacy

\begin{tabular}{|c|l|}
\hline Level & \multicolumn{1}{|c|}{ Student Achievement Description Level } \\
\hline 1 & $\begin{array}{l}\text { Students are able to identify the information contained in the problem then complete with routine } \\
\text { procedures according to instructions that have been presented directly. Students can answer questions } \\
\text { that are of common context. }\end{array}$ \\
\hline 2 & $\begin{array}{l}\text { Students are able to identify the mathematical relationship between textual information and data then } \\
\text { interpret the information and apply simple models and give reasons directly from the results obtained. }\end{array}$ \\
\hline 3 & $\begin{array}{l}\text { Students can choose and apply simple strategies, students can carry out procedures well, including } \\
\text { procedures that require successive decisions. }\end{array}$ \\
\hline 5 & $\begin{array}{l}\text { Students are able to calculate a mathematical problem consisting of many contexts and use procedures } \\
\text { and are able to communicate based on interpretation, results and actions. }\end{array}$ \\
\hline 6 & $\begin{array}{l}\text { Students are able to use broad reasoning and communicate that reasoning, reflect on the results of their } \\
\text { work, and can precisely relate their mathematical knowledge and skills to the situation at hand. }\end{array}$ \\
\hline
\end{tabular}

Mathematical literacy skills become one of the most important factors that students must master because indirectly in the process of mathematical literacy train students to better understand mathematics as a meaningful subject and not just calculations or formulas. This is what makes students have to get used to reading situations and hooking up in mathematical ideas. But as is known, that the results of the PISA assessment in Indonesia have not been in line with expectations. This is characterized by low scores and test scores of students in Indonesia in 2018, namely for the mathematics category, ranked below with an average score of 379 .

The low achievement of mathematics students is inseparable from one of the factors, namely the mathematical disposition of students. Students' interests when dealing with mathematics are also influential in the learning process and outcomes [4]. Mathematical disposition is a person's behavior towards mathematics that can give rise to a tendency to observe mathematics as something reasonable and useful. Mathematical disposition is fundamentally important for everyone who will learn mathematics, because mathematical disposition has influence and contains ways to acquire knowledge, skills and attitudes that will be reflected in daily life [5]. Indicators of mathematical disposition [6], among others:
1. Confidence in using mathematics, solving problems, communicating ideas, and giving reasons.

2. Flexibility in investigating mathematical ideas and trying to find alternative methods of solving problems.

3. Have the determination to complete math tasks

4. Interest, curiosity, and ability to find in doing math tasks

5. Tend to see and reflect their own reasoning.

6. Assessing mathematical applications to other situations in other fields Awards the role of mathematics in the culture and value of mathematics, as a tool and language.

Based on indicators, disposition can reflect students' attitude, interest and confidence in problem solving, communicating ideas and giving reasons in solving math problems. Disposition is also related to the assessment of the application of mathematics in other fields and sees mathematics as something related to everyday situations and events, so that the disposition relates to mathematical literacy. Students who understand a concept meaningfully do not necessarily have a comfortable feeling when learning so that students who have high mathematical abilities do not necessarily have a high disposition and vice versa [7]. Different levels of mathematical disposition lead to different levels of student math literacy as well 
[8]. A mathematical disposition includes a willingness to take risks and explore solutions to diverse problems, perseverance to solve challenging problems, a willingness to try different ways to explore mathematical concepts and see problems as challenges [9].

Based on the data, Try to examine more broadly the mathematical literacy ability of students who have a high mathematical disposition in solving problems similar to PISA. By knowing the mathematical literacy ability of students who have a high mathematical disposition is expected to provide input to educators to know the characteristics of students in improving learning achievement.

\section{METHOD}

The method used is qualitative descriptive. The purpose of this study is to describe the mathematical literacy skills of students of class IX integrated Islamic Junior High School Nur Hidayah Surakarta in solving similar problems pisa school year 2020/2021. The instruments used are mathematical disposition questionnaires, mathematical literacy tests and interview guidelines. All instruments have been validated by expert validation.

Mathematical disposition questionnaires are used to group students who have high, medium and low. After grouping, students are given a mathematical literacy test question, then conduct an interview with the selected subject. Indicators used in interviews include the student's level of difficulty, questions about the student's strategy in completing and how to argue.

The determination of the study subject was carried out using a test of the results of the haunted filling of mathematical disposition. Questionnaire is given to the ninth grade D consisting of 29 students. The results of the questionnaire intrusion analysis can be seen in the following table:

Table 2. Mathematical disposition poll results

\begin{tabular}{|l|c|}
\hline Mathematical disposition & Number of students \\
\hline High & 9 \\
\hline Moderate & 12 \\
\hline Low & 8 \\
\hline
\end{tabular}

Based on the results of the questionnaire selected 2 subjects from 9 subjects that have a high mathematical disposition. Subject assignments are selected based on the variety and completeness of information from the student's answers. The next stage is to give a mathematical literacy test to the subject. The problem given is in the form of a similar PISA. In the test study used consisted of 5 points of similar PISA problems in the form of descriptions with each indicator of mathematical literacy ability.

The data analysis techniques in this study use reflective data analysis. Data reduction or presentation of data is done after obtaining data, then the next activity is reciprocal. This study used triangulation methods. Written test results and interviews are analyzed using mathematical literacy indicators. If the test results are written with the interview results while the same data then the data obtained is valid data.

\section{RESULT AND DISCUSSION}

The problem given is in the form of a similar PISA. In this study, subjects got a mathematical literacy problem of 5 questions consisting of levels 1 to level 6.

\subsection{Students' Mathematical Literacy Skills at level 1}

In question number 1 , the problem presented is still given a clear description and the context is general. Given the question of the price data of an item and calculating the minimum price, students can complete it using routine procedures based on the data and instructions presented. Here's an excerpt of the subject's written answer in Figure 1.

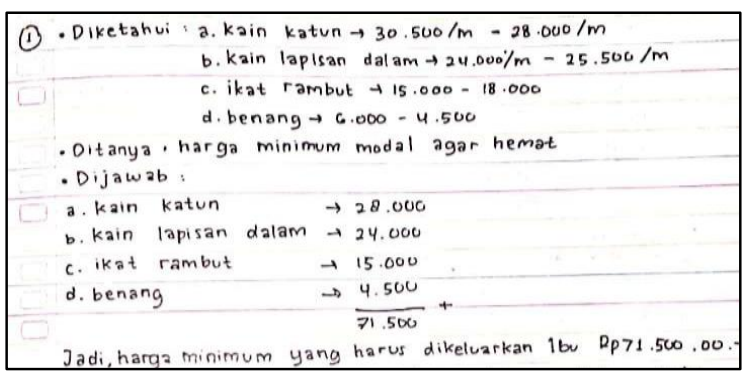

Figure 1 Subject answer result 1

Figure 1 is one of the results of the subject's answer indicated by a complete and complete process of workmanship. In problem number 1 with the ability of mathematical literacy level 1 is classified as a problem with a low level of reasoning, although it already requires the ability of representation to solve it. All the information and information needed in answering the problem has been clearly presented in the problem. 
Based on data analysis subject 1 and subject 2 were able to solve the question with the correct answer. Although both subjects can answer but the S1 is not accompanied by a clear way, the subject only mentions the lowest price. For S2 answer in a clear and sequential way, from starting to mention the lowest price then give an explanation by summing the lowest price on each of these items then just get the final result.

This is supported by the results of the interview which states that: 1) both subjects can explain the intent and information in the problem, 2) the subject is able to present the reason appropriately. In problem number 1 which is at level 1 both subjects are able to explain explicitly all procedures in solving the problem and both subjects can also perform actions correctly in accordance with the stimulus that has been given.

\subsection{Students' Mathematical Literacy Skills at level 2}

In question number 2 with mathematical literacy ability level 2 is classified as a problem with a low level. Problem number 2 relates to the comparison of a grade, students can determine a lesser price to rent a house. In this question is no longer given assistance in the form of information that can be immediately concluded, but students need to process the information first until getting the final settlement. Given the question of renting prices, students can use a simple model and identify the relationship between information in the form of payment options and data on which calculations are more cost-effective. Here's an excerpt of the subject's written answer in Figure 2.

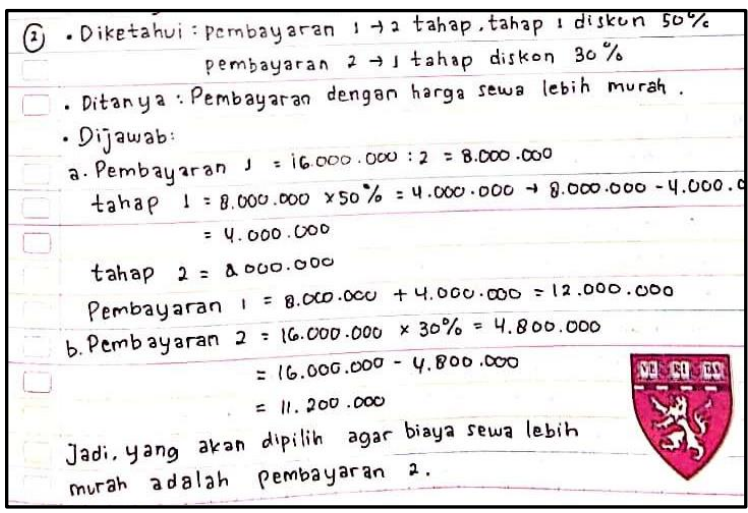

Figure 2 Subject answer result 1

Based on the data analysis of both subjects precisely in solving the problem. Subjects have the same way or strategy in the completion process. The subject is able to link the information available to the question and then perform the calculation according to the procedure and can provide the correct and precise reasons as in Figure 2. Based on the summary of the interview obtained the following results: 1 ) the subject has no difficulties and is able to communicate the answer clearly, 2) the subject explains the order of work and then relates if the problem occurs in daily life then the chosen one is the rental cost of less value or price. This shows that at level 2, all subjects can solve it with the right and correct answers so that subjects with high mathematical disposition can achieve all indicators of level 2 mathematical literacy skills.

\subsection{Students' Mathematical Literacy Skills at level 3}

In question number 3 with level 3 mathematical literacy skills. Problems at level 3 can be categorized as problems that use a moderate level of reasoning. Given the question of making hand sanitizer. There are several materials available and materials required. Students can devise a simple strategy and use a specific representation to determine the number of hand sanitizers that can be made based on available materials and subjects can determine the remaining materials. Here's an excerpt of the subject's written answer in Figure 3.

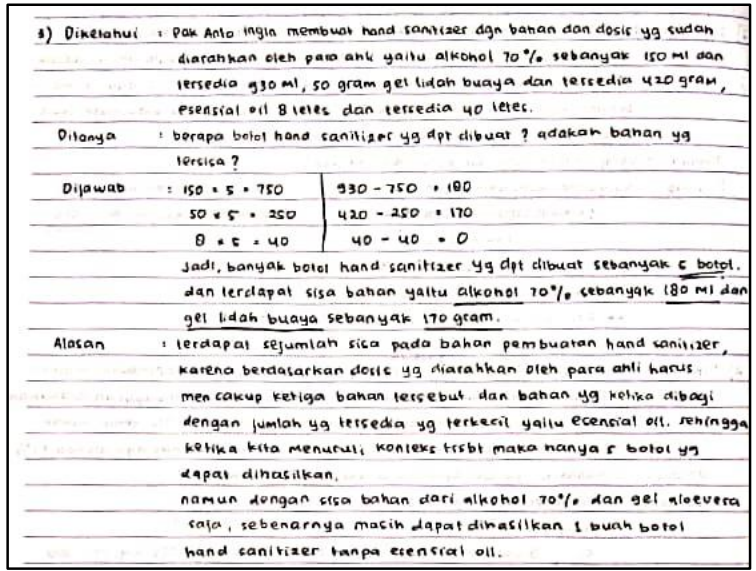

Figure 3 Subject answer result 2

Based on the results of the data analysis the subject is very careful in understanding the meaning of the problem. The subject is able to interpret the details contained in the question and then be able to choose the strategy to be done. In Figure 3 it appears that the subject can work with the right procedure, starting with the first step which is to share each available material with the required materials then see the material that has been out of stock then the hand sanitizer that can be made is also maximal. This is 
supported by the results of interviews to the subject of research. Summary of the interview as follows: 1) the subject at the beginning of reading the question was confused but when understood again and read repeatedly, the subject can understand the intent in the question, 2) the subject is also able to explain why using the strategy, the reasons presented are very clear and acceptable. This shows that at level 3 the math literacy skills of students who have a high mathematical position can solve problems well.

\subsection{Students' Mathematical Literacy Skills at level 4}

In question number 4 with level 4 mathematical literacy skills. This problem requires high reasoning, although it has not reached the complex. Problem number 4 requires students to be able to make representations of the results of their work and be able to relate to real situations. This question relates to the subject matter of scale and time. Where to solve this problem the subject must be able to use his mathematical ability in determining the time it takes to reach the destination by combining the information contained in the problem. Here's an excerpt of the subject's written answer in Figure 4.

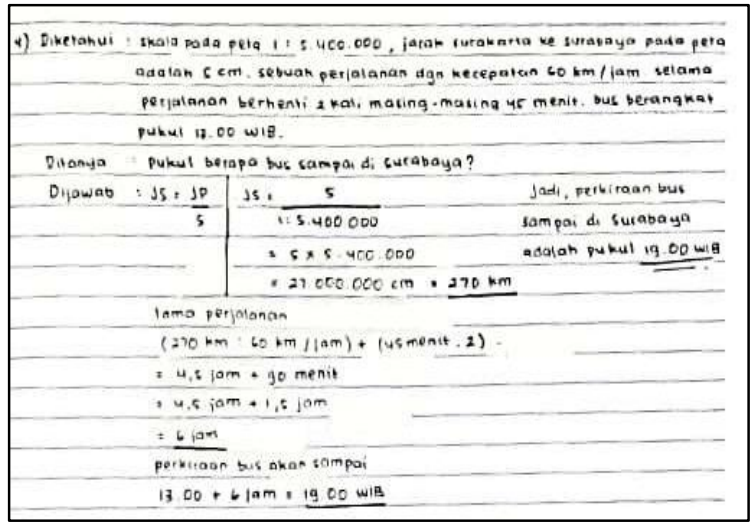

Figure 4 Subject answer result 2

Based on the results of the data analysis, both subjects were able to finish with the correct answer. Although both subjects performed different procedures, they were able to use mathematical ideas as shown in Figure 4. Some of the information implied, both with the distance on the map and the time the subject had no difficulty in interpreting. Then the subject is also able to connect the available information and able to computation precisely and thoroughly. The step taken by the subject of this study is to calculate the length of distance on the map by interpreting the line located on the map using the existing information to be able to determine the actual distance and the subject can calculate the time it takes on the journey. This is also supported by the results of the interview, here is a summary of the interview: 1) the subject does not find it difficult to understand the problem because the material about distance and time has often been studied, 2) the subject does not experience difficulties when explaining the remaining material smoothly.

\subsection{Students' Mathematical Literacy Skills at level 5 and level 6}

In question number 5 consists of two questions with mathematical literacy skills level 5 and 6 . In the first question is a question with level 5, Problems at this level require a higher understanding to be able to connect initial knowledge and mathematical skills and be able to make guesses and reflection statements in the problem then able to communicate it. This problem relates to the broad concept of flat wake. Students should look by knowing the average size per day of weaving obtained by a proficient weave. Then substitute the area of fabric woven daily into the area of the fabric woven a few days.

For the second question with level 6 , in this problem students can create mathematical concepts by using information based on difficult and complex problem situations. Students can use their knowledge in depth with a high level of reasoning. Students can draw up a plan to determine which one is fastest increasing between the area of the woven fabric or the number of floral motifs on the fabric then the student can give a logical reason. Here's a picture of the student's work in Figure 5 and Figure 6.

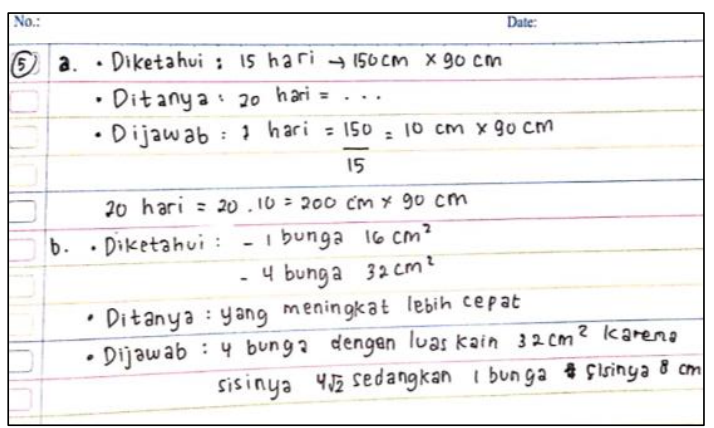

Figure 5 Subject answer result 1

In Figure 5, the subject has been able to strategize well but the caption is incomplete. This is different from the answer by subject 2 in Figure 6, subject 2 is precise in understanding the question and the resulting answer fully explains with the steps in each completion process. In Figure 5 for level 6 on question $5 \mathrm{~b}$ subject 1 is not yet correct in providing answers and 
reasons. In the settlement it appears that subject 1 lacks understanding of the meaning of the problem, should only compare which ones increase faster instead of comparing many interest. In Figure 6 for the second subject has answered correctly, but the reason given cannot answer the question or still unclear. This indicates that the subject at level 6 has not been able to understand the problem as a whole. The strategy used has also not been able to describe the ability of students to use their mathematical ideas. Based on the summary of the interview results as follows: 1) the subject has not been able to communicate the procedure which is why the step is like that, 2) the subject has not been able to combine the information contained in the question because the subject still feels confused in understanding the meaning of the question in the question.

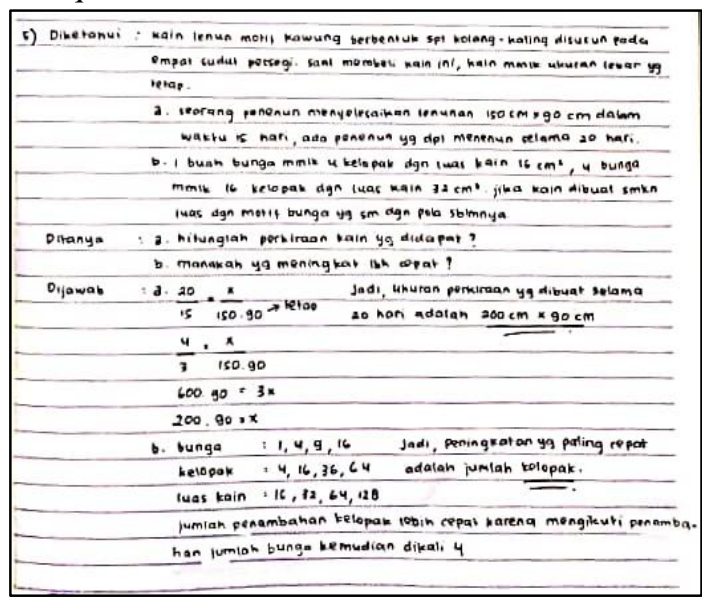

Figure 6 Subject answer result 2

From the results of data analysis at each level, for level 1 to level 5 students have been able to complete with the correct procedures. The higher the level has a different level of difficulty but students are able to finish well despite the need for repeated understanding at a higher level of the problem. Obtained results that state that students who have a high mathematical disposition still have difficulty when working on the problem of mathematical literacy skills at level 6. This is shown by the results of the mathematical literacy ability test that the subjects who have not been able to answer with the correct strategy so that the results obtained are still not correct. Students have difficulty solving problems due to their inability to implement strategies as a step in verifying solutions to problems before they come to a conclusion.

Students who have a high mathematical disposition will form a tenacious, responsible and high-achieving person and can help individuals achieve the best results. Students with high mathematical dispositions can perform all stages of problem solving in Polya theory [10]. Mathematical disposition can affect mathematical literacy skills [11]. There is a positive relationship between attitudes towards mathematics and mathematical achievements [12]. Students who have a positive view of mathematics will try to solve a problem. Students with a positive mathematical disposition have high mathematical abilities [13]. Students also often associate problems in everyday life so that it is easier to find solutions. In communicating the answers students have high self-confidence and tend to reflect on their own reasoning. Students who have a high mathematical disposition will be more persistent and diligent in solving problems, and can make good habits in math learning [14]. One of the basic competencies of a student's mathematical literacy ability is the ability to solve problems. Thus it is seen that students who have a high mathematical disposition have interest, earnestness, tenacious and always understand the usefulness of mathematics in other fields they tend to be able to imitate mathematical problems that require a level of reasoning that is more like solving problems similar to PISA. Where the problems presented are one of the tools to measure the mathematical literacy ability of students.

\section{CONCLUSION}

Based on the results and discussion, it can be concluded that the mathematical literacy ability of students who have a high mathematical disposition in solving PISA-like problems can solve problems up to level 5. Students who have a high mathematical disposition are able to explain the procedure in full and accompanied by the right reasons, are able to use their thinking extensively and can combine their mathematical skills and knowledge. Although there are differences in writing information on the solution process, but conceptually the subject has been able to master. In communicating the answers students have high self-confidence and tend to reflect on their own reasoning. In level 6 the subject does not understand the meaning of the problem but at this level the subject already has a strong determination to complete so as to produce a final answer that is accompanied by reason although still not accurate.

Teachers can give questions that vary on par with PISA problems or teachers can provide examples of problems related to real situations or that are currently 
up to date and use high reasoning, so that students can apply their reasoning skills as a tool to solve problems in a wider situation.

\section{ACKNOWLEDGMENTS}

Researchers expressed their gratitude for Nur Hidayah Integrated Islamic Junior High School Surakarta for their assistance and cooperation until the researchers were able to complete the data related to the study in analyzing students' mathematical literacy skills reviewed from the student's mathematical disposition.

\section{REFERENCES}

[1] OECD. (2015). PISA 2015: Draft Mathematics Framework. Paris: OECD Publishing.

[2] Ojose, Bobby 2011 Journal of Mathematics Education. 4 89-100 National Council of Teacher of Mathematics (NCTM). (1989). Curriculum and evaluation standards for school mathematics. Reston, VA : Authur

[3] OECD. (2019). PISA 2018 Assessment and Analytical Framework. Paris: OECD.

[4] Feldhaus, C. A. (2014). How Pre Service Elementary School Teachers' Mathematical Dispositions are Influenced by School Mathematics. American International Journal of Contemporary Research, 4(6), 91-97.

[5] Kusmaryono, I. (2014). The Importance of Mathematical Power in Mathematics Learning. International Conference on Mathematics, Science, and Education 2014 (ICMSE 2014), 2014(ICMSE), 35-40.

[6] N. C. of T. of Mathematics, Principles and Standards for School Mathematics. United States of America, 2000.

[7] Widyasari, Nurbaiti. (2016). Meningkatkan kemampuan disposisi matematis siswa SMP melalui pendekatan Metaphorical Thingking. Jurnal Pendidikan Matematika dan Matematika, 22 28-39.

[8] Sumarmo, U. (2012). Pendidikan karakter serta pengembangan berfikir dan disposisi matematik dalam pembelajaran matematika. In Seminar Pendidikan Matematika (Vol. 25).

[9] Putra, A. K., Budiyono, \& Slamet, I. (2017). Mathematical disposition of junior high school students viewed from learning styles. AIP Conference Proceedings, 1868(August). https://doi.org/10.1063/1.4995152
[10] Yustiana, Y., Kusmayadi, T. A., \& Fitriana, L. (2021). The Effect Mathematics Disposition of Vocational High School Students on Mathematical Problem-Solving Ability. IOP Conference Series: Earth and Environmental Science, 1808(1). https://doi.org/10.1088/17426596/1808/1/012049

[11] Dewi, T. A. (2016). Kemampuan Literasi Matematika Siswa Kelas X pada Pembelajaran CIRC Bernuansa SPUR Ditinjau dari Disposisi Matematika. PRISMA, Prosiding Seminar Nasional Matematika, 121-130. Retrieved from https://journal.unnes.ac.id/sju/index.php/prisma/ article/view/21439

[12] Mullis, Martin, Foy P., Arora, A. (2012). TIMSS 2011 International Result in Mathematics. Reston, VA: Authur

[13] Kusmaryono, I., Suyitno, H., Dwijanto, D., \& Dwidayati, N. (2019). The effect of mathematical disposition on mathematical power formation: Review of dispositional mental functions. International Journal of Instruction, 12(1), 343356. https://doi.org/10.29333/iji.2019.12123a

[14] Mahmudi, A. (2010). Tinjauan Asosiasi antara Kemampuan Pemecahan Masalah Matematis dan Disposisi Matematis. Makalah Disajikan Pada Seminar Nasional Pendidikan Matematika FMIPA UNY, 17(April), 1-11. 